\title{
Stunting Prevention Policy as a Form of Child Health Rights Legal Protection
}

\author{
Hartotok Hartotok $^{1 *}$, Absori Absori(D) ${ }^{1}$, Khudzaifah Dimyati(iD) ${ }^{1}$, Heru Santoso $\mathbb{D}^{2}$, Arief Budiono (iD ${ }^{3}$ \\ ${ }^{1}$ Doctoral of Law, University of Muhammadiyah Surakarta, Surakarta, Indonesia; ${ }^{2}$ Department of Midwifery, Poltekkes Kemenkes \\ Surabaya, Indonesia; ${ }^{3}$ Faculty of Law, University of Muhammadiyah Surakarta, Surakarta, Indonesia
}

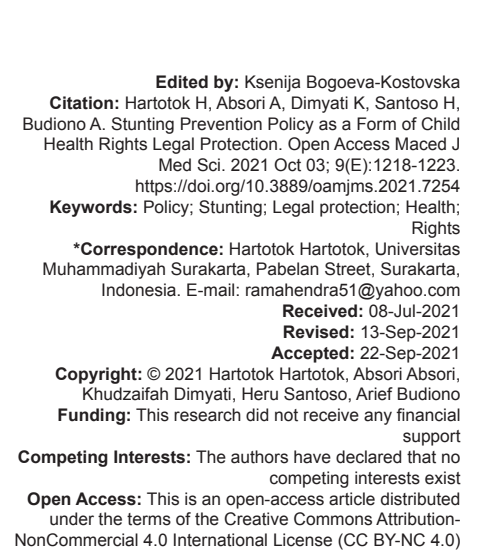

Abstract

AIM: The objectives of this research are to reveal and to analyze the stunting prevention policy as a form of legal protection for children's health rights (HR).

METHODS: This type of research is a normative legal research approach to the legislation approach and conceptual approach.

RESULTS: The results of the study show that stunting prevention policy as a form of legal protection for child HR has not been able to reduce the number of stunting. The high prevalence of stunting as evidence of the government's failure in legal protection against the problem of malnutrition. Ignoring children's rights is a form of HR violations committed by the state.

CONCLUSION: Need to regulate the law related to stunting as a manifestation of state responsibility in upholding children's rights. Prevention and handling of stunting are carried out holistically in various sectors with commitment and synergy between the central/regional government, parents, family, and community.

\section{Introduction}

The quality of health resources (hereinafter referred to as Health Rights [HR]) is an absolute requirement for development in all fields. Nutritional status is one of the factors that play a very important role in the quality of $H R$, especially those related to intelligence, productivity and creativity. A healthy child will experience normal and reasonable growth and development, which is according to the standard of physical growth of children in general and has the ability according to the standard of ability of children his age. The growth of children in the $3^{\text {rd }}$ year is so fast and gradually decreases that in the preschool and school periods the growth acceleration curve will form an almost flat curve [1].

HR development starting in 2019 and subsequently becoming the mainstream of Indonesia's future development strategy, the choice of strategy is sought to accelerate the economic growth needed to improve people's welfare. This HR development is a program of President Joko Widodo which was delivered in his state speech at his inauguration starting the second term of President Joko Widodo.
In view of the foregoing, the prevention of stunting is a priority in President Joko Widodo's program for the second period. Stunting, according to Bloem et al., is a chronic nutritional problem caused by multi-factorial and intergenerational nature. In Indonesia, people often consider growing short as a hereditary factor. Misperceptions in society make this problem difficult to solve and requires great efforts from the government and various related sectors. The results of the study prove that the influence of heredity only contributes $15 \%$, while the largest element is related to problems with nutrient intake, growth hormones, and the occurrence of recurrent infectious diseases [2].

The period of the first 1000 days of life (1000 HPK) is a critical node as the beginning of stunting growth, which, in turn, has a long-term impact that repeats itself in the life cycle. Malnutrition as a direct cause, especially in children under five, has a short-term impact on increasing morbidity. If this problem is chronic, it will affect cognitive function, namely, a low level of intelligence and has an impact on the quality of human resources. In repeated conditions (in the lifecycle), children who experience malnutrition in early life (1000 HPK period) have a risk of non-communicable diseases in adulthood [3]. 
Children's food intake is often low in quantity and quality. Good quality food intake is an important component in children's diets because they contain sources of macronutrients (carbohydrates, fats, and proteins) and micronutrients (zinc and calcium) which all play a role in children's growth [4]. Research in Bogor in children aged 6-12 months stated that growth disorders can be caused by a single deficiency or a combination of micronutrients such as zinc and calcium [5].

Law Number 17 year 2007 concerning LongTerm Development Plans for 2005-2025 (hereinafter referred to as RPJP Law) states that food development and nutrition improvement are carried out across sectors including production, processing, distribution, to consumption of food with sufficient, balanced, and guaranteed nutritional content. Furthermore, Law Number 36 year 2009 concerning Health (hereinafter referred to as the Health Law) states that the direction of nutrition improvement is to increase the nutritional quality of individuals and communities through improving food consumption patterns in accordance with balanced nutrition; improvement of nutrition conscious behavior, physical activity, and health; increasing access and quality of nutrition services in accordance with advances in science and technology; and improvement of the food and nutrition awareness system. In line with these two laws, Law No. 18 year 2012 was issued concerning Food (hereinafter referred to as the Food Law) which stipulates policies in the food sector to improve the nutritional status of the community. The Government and Regional Governments prepare a Food and Nutrition Action Plan every 5 years.

Concerning food (hereinafter referred to as the Food Law) which stipulates policies in the food sector to improve the nutritional status of the community. From the three laws, the Presidential Regulation (Perpres) Number 5 year 2010 concerning the MediumTerm Development Plan (2010-2014) stated that the direction of Food and Nutrition Development is to improve food security and the health and nutrition status of the community. Furthermore, Presidential Instruction (Inpres) Number 3 year 2010 concerning the Preparation of the National Action Plan for Food and Nutrition (RAN-PG) 2011-2015 and the Regional Action Plan for Food and Nutrition (RAD-PG) 2011-2015 in 33 provinces Regional Governments prepare the Food Action Plan and Nutrition every 5 years.

Presidential Regulation (Perpres) Number 42 of 2013 concerning the National Movement for Nutrition Improvement was issued to support efforts to raise stakeholder participation and concern in a planned and coordinated manner to accelerate nutrition improvement in the first 1000 days of life (1000 HPK). Thus, policy support instruments in accelerating nutrition improvement are quite complete, and require organized implementation efforts that can be applied at every level by every element involved. With the issuance of this Presidential Regulation, more concrete efforts are needed, focusing on 1000 HPK and integration of activities across programs (specific efforts) and cross-sectorial (sensitive efforts) by all stakeholders.

In addition, in various laws and regulations regulate children's rights to life such as Law Number 4 of 1979 concerning Child Welfare (Child Health Law), Law Number 23 of 2002 concerning Child Protection (Child Protection Law), Law No, Law Number 36 of 2009 concerning Health (Health Law), and even regulated in Law Number 39 of 1999 concerning Human Rights (Human Rights Law). The fact is that stunting sufferers are relatively high or still below the standard set by WHO $20 \%$. Stunting should be a concern of the government, given the serious impact it has on children and has implications for the nation's future. Based on this phenomenon, the focus of the study in this research is the stunting prevention policy as a form of legal protection for the HR of children.

\section{Formulation of the Problem}

The formulation of the problem in this research is put forward in the form of questions: "How is the policy of preventing stunting as a form of legal protection for the HR of children?"

\section{Research Purposes}

The purpose of this study is to identify and analyze stunting prevention policies as a form of legal protection for children's HR (Children's HR).

\section{Research Methods}

This research is a normative legal research with a statute approach (legal approach) and a conceptual approach (conceptual approach). Considering that this type of research is based on normative research, most of the data and legal materials used refer to secondary data which includes primary legal materials, consisting of various laws and regulations, jurisprudence, and conventions related to policy. Stunting prevention as a form of legal protection for children's HR (Children's HR).

In collecting data, researchers conducted a literature search (library research), both extensively and intensively. Literature research aims to study, research, and trace secondary data, in the form of legal materials. Legal materials are normative-perspective, 
used primarily to examine legal issues related to the substance of the positive legal regulations (ius constitutum) which regulate stunting prevention policies as a form of legal protection for children's HR, Based on the binding force, they are classified as primary legal materials, secondary legal materials, and tertiary legal materials [6]. The data analysis technique used is a juridical analysis, namely, an analysis based on theories, concepts, and laws and regulations.

\section{Discussion}

Factors causing stunting are low energy intake, infectious diseases, low maternal education, children do not get exclusive breastfeeding, low protein intake, low education of fathers, and working mothers, maternal gestational age who is too young (under 20 years) is at risk of giving birth to babies with heavy weight. Low-birth weight (LBW). LBW infants affect about $20 \%$ of the occurrence of stunting. In addition, the low nutritional intake for prospective pregnant women (adolescent girls) and the low attention of mothers to exclusively breastfeed their children for up to 6 months, inadequate provision of complementary feeding (MP-ASI) causes stunting [7]. In addition, the factors that cause stunting are: first, poor parenting practices, including the lack of knowledge of mothers about health and nutrition before and during pregnancy, as well as after the mother gives birth, second, still limited health services, third, the lack of household access/family to nutritious food, fourth, lack of access to clean water, and sanitation [8].

Stunting is a multidimensional child health problem so that the government has determined stunting as one of the priority programs based on Law Number 36 year 2009 concerning Health (Health Law) and Law Number 18 year 2012 concerning Food (hereinafter referred to as the Food Law). On that basis, the government made several policies, namely, the issuance of Presidential Regulation Number 42 year 2013 which regulates the Implementation of the National Movement for the Acceleration of Nutrition Improvement. The Roadmap for Accelerating Nutrition Improvement consists of four main components which include advocacy, cross-sectorial strengthening, development of specific and sensitive programs, and database development. Both direct (specific) and indirect (sensitive) nutrition interventions need to be carried out jointly by ministries/agencies and other stakeholders [9]. Regulation of the Minister of Health Number 17 year 2018 concerning Amendments to the Regulation of the Minister of Health concerning General Guidelines for Distribution of Government Assistance within the Ministry of Health by Providing Supplementary Food for Pregnant Women and
Toddlers and Providing Nutrition Education in Providing Local Supplementary Foods for Pregnant Women and Toddlers. In 2019, the Minister of Villages signed the Permendes PDTT No. 16 year 2018 Utilization of village funds for Posyandu, Minister of Health Regulation Number 39 year 2016 concerning Guidelines for the Implementation of the Healthy Indonesia Program with a Family Approach. Therefore, efforts made to reduce the prevalence of stunting are focused on pregnant and maternity mothers, toddlers, school-age children, adolescents, and young adults [10].

Several programs have been recorded from the field and have been implemented, namely first, Rice for the Poor (Raskin)/Rice for Prosperity (Rastra) (Bulog); second, Non-Cash Food Assistance (Ministry of Social Affairs); third, the Family Hope Program/PKH (Ministry of Social Affairs); fourth, Supplementary Feeding/PMT for pregnant women (Ministry of Health); and fifth, food aid from other sources (local government, NGOs, and others) [11].

Based on the reality that government programs have not been achieved and their implementation is uneven. According to data from the Ministry of Health, the prevalence of stunting under-five in Indonesia from 34 provinces is only two provinces that are under the WHO limit, namely Yogyakarta (19.8\%) and Bali $(19.1 \%)$. Other provinces have high and very high predominant cases of around $30-40 \%$. The issue of the gap between the policy and the implementation of the population's food security program is as follows [12].

1. Interested parties have never collected data on poor families. So that the fulfillment of healthy food needs is based on the facts of data on energy and protein deficits (the calculation of malnutrition for every poor family that must be met is $500 \mathrm{kcal}$ and $10 \mathrm{~g}$ of protein/cap/day)

2. In the field, there are many programs for providing food assistance or PMT from nonstandard sources; and

3. There is no specific policy regarding the fulfillment of nutrition for pregnant women, breastfeeding mothers, infants, toddlers, and other nutritionally vulnerable groups.

According to Titon Slamet Kurnia, the occurrence of malnutrition is a failure of the government in realizing food security, both as administrators and as regulators. This failure confirmed the existence of a legal obligation that was violated by the government even though the government then tried to evade responsibility by proposing various forgiving reasons such as unfavorable natural conditions, and economy. In fact, dealing with malnutrition/stunting means alleviating poverty. Poverty is a condition that closes human accessibility in various possibilities. The closure of accessibility is an obstacle to the implementation of one's human rights. Therefore, eradicating poverty is a major part of the HR enforcement strategy [13]. 
Based on the legal system theory as stated by Lawrence M. Friedman that efforts to enforce the law on children's constitutional rights as guaranteed by the 1945 Constitution of the Republic of Indonesia (UUD NRI 1945) and Article 52 paragraph (2) of the Human Rights Law which mandates that carried out both through aspects of legal substance (rules), structure and cultural aspects. Aspects of substance, HR are one of the children rights and for its interests children's rights are recognized and protected by law. Based on these considerations, the state ratified several laws and regulations with legal substance guaranteeing children's HR which are basic rights that are naturally inherent in children which must be protected, respected and defended by everyone. National law has guaranteed the implementation of children's rights in general, but it is not enough because there are no laws and regulations that explicitly regulate the rights of children with stunting.

As previously described, stunting is a multidimensional problem, so its handling must be multifactorial. In its implementation, it is necessary to have special rules governing stunting with legal content, namely, first, the rights and obligations of children with stunting; second, the responsibility of the central government and local governments; third, the rights and obligations of parents; fourth, the professionalism of health services in the prevention and management of stunting; fifth, community participation; sixth, facilities, and infrastructure; fifth, supervision; and sixth, legal sanctions to the executor of duties, the community, and to parents who ignore their obligations which result in the children's rights not being fulfilled. Legal sanctions are very urgent to exist in a rule, because sanctions are a coercive tool so that a rule can be implemented so as to guarantee legal certainty and provide benefits.

Aspects of the structure, globally the policies carried out to reduce the incidence of stunting are focused on the first 1000 days group or what is called Scaling up Nutrition. The WHO recommends reducing stunting by $3.9 \%$ per year to meet the target of $40 \%$ stunting reduction by 2025 . Interventions are carried out throughout the lifecycle both in the health and non-health sectors involving various levels of society such as the government, private sector, civil society, the United Nations through actions collective efforts to improve nutrition, both in the short term (specific intervention) and long term (sensitive) [14].

Handling stunting cannot be done individually (scattered) because it will not have a significant impact. Stunting prevention efforts must be carried out in an integrated and convergent manner with a multi-sectorial approach. Therefore, the government must ensure that all ministries/agencies as well as development partners, academics, professional organizations, civil society organizations, private companies, and the media can work hand in hand in efforts to accelerate stunting prevention in Indonesia. Not only at the central level, integration and convergence of stunting prevention efforts must also occur at the regional level to the village level [15].

From these problems, what is really needed in upholding the HR of children with stunting is synergy, a fair commitment between the government, parents, families and communities in implementing children's HR as demands for human rights in a sovereign country.

In implementing the acceleration of stunting prevention, various obstacles were found, including the ineffectiveness of stunting prevention programs and the ineffective and inefficient allocation and utilization of resources and funding sources [16]. It is hoped that in the implementation of the Permendes for the development of underdeveloped areas and public transmigration in 2019, which is the main reference for villages throughout Indonesia, the village government will prioritize the needs that cause stunting in rural areas such as improving health facilities, access to clean water, and fulfilling nutritional needs for mothers and child. According to Ahmad Ali, the effectiveness of a rule depends on the optimization and professionalism of law enforcement officers to enforce the enactment of the rule of law starting from the making, socialization to the law enforcement process [17].

Cultural aspect, the determinant factor that determines nutritional conditions is socio-cultural, namely, knowledge of human nutrition must be equipped with knowledge of people's lives. Some people still believe in myths which are knowledge inherited from their ancestors, such as babies whose teeth have not yet grown are not allowed to eat (do not know MPASI) [18].

The low knowledge of mothers is one of the factors that do not fulfill children's rights. Breastfeeding continued with complementary feeding (MPASI) for up to 2 years is a process to help the growth and development of infants and children. Policies and strategies that regulate this parenting pattern are contained in Article 128 of the Health Law, Government Regulation Number 33 year 2012 concerning Breastfeeding, and the Strategic Plan of the Ministry of Health 2015-2019, Decree of the Minister of Health Number HK.02.02/MENKES/52/2015. Therefore, there is a need for coaching, counseling, premarital education so that there is a paradigm shift in society. Because the food eaten is largely determined by local social, economic, and cultural conditions.

The right to health is the right of every human including children being that is guaranteed in the legislation. The reality found is that discriminatory health services are still found. It is proven by the number of related reports that services are still not optimal and there is discrimination treatment for some people. Poor patients (children aged 5 years) receive discriminatory health services. Actions that discriminate against children's rights constitute a violation of constitutional rights as affirmed in the 1945 Constitution of the 
Republic of Indonesia that "Everyone has the right to be free from discriminatory treatment on any basis and has the right to protection against such discriminatory treatment." According to Majda, human rights require individuals to be recognized as having access to health care quickly and at an affordable cost [19].

Stunting does not only occur in the poor or only in rural areas but also in the rich and also in urban areas. The results of the study indicate that one of the factors causing stunting is a working mother (career woman). This factor is caused by the lack of family awareness about nutrition fulfillment. Mothers who do not care about their children's rights to exclusive breastfeeding, due to their unfashionable appearance, are a violation of HR against children. Article 200 of the health law stipulates that the state should be responsible for this problem so that sanctions are not only imposed on those who hinder breastfeeding, but also must be given to mothers who intentionally do not give exclusive breastfeeding except for medical reasons.

The government continues to work in protecting children from stunting, although it focuses more on prevention rather than treatment. This action shows that the government has not been serious (political will) in protecting children's rights, especially for stunting sufferers. Recovery of children's health from stunting must be a concern of the government so that children return to health. The enforcement of children's HR will be more effective by increasing supervision in implementing stunting prevention and management.

All efforts made by the government must be based on the spirit that the existence of a state of law must be able to make its people happy in accordance with the goals of the state based on the spirit of empathy, dedication, determination, and high commitment [20]. Supposedly, not only the government is obliged to uphold $\mathrm{HR}$ as a human rights, but also the general public, especially parents and families. However, one thing to remember is the need for professionalism so that the development, enforcement, and promotion of human rights are not arbitrary. The expected enforcement and promotion of HR are in accordance with the legal corridors as Indonesia is a democratic state of law [21].

The failure of the state in carrying out its obligations can be used as a basis for prosecution in courts in the context of upholding human rights. Although, there is a rejection of state accountability as the theory of state sovereignty that state power is supreme and unlimited so that the state can impose its will regardless of other parties so that it is impossible to be prosecuted in court. However, as a state of law (rechstaat), it is not impossible that the state cannot be prosecuted in court. The state has violated the most fundamental rights, namely the right to life which is a given from God Almighty and the right to healthcare which is a right recognized in the constitution and comes from the state.

\section{Conclusions and Suggestions}

\section{Conclusions}

Based on the discussion that has been stated above, it can be concluded that the stunting prevention policy is a form of legal protection for children's HR has not succeeded in reducing the prevalence of stunting. The high prevalence of stunting is evidence of the government's failure to protect the law against malnutrition. Ignoring children's HR is a form of human rights violations committed by the state. There is a need for legal arrangements related to stunting as a manifestation of the state's responsibility in upholding children's human rights. Stunting prevention and management is carried out holistically in various sectors with commitment and synergy between the central/ regional government, parents, families and communities.

\section{Suggestion}

As for suggestions that can be put forward related to the protection of the HR of children indicated by stunting, the government is advised to provide intensive treatment in facilitating the recovery of children's health by improving the nutritional intake of stunted children. Legal protection for children with stunting must be carried out holistically in various sectors with a high commitment and synergy between the government, parents, families, and communities.

\section{Thank-you Note}

The authors thank Allah SWT, considering that it is his pleasure that the writing of articles can be completed, the same thing is also true for the Doctoral Program in Law, Muhammadiyah University of Surakarta because during my lectures I gained a lot of knowledge so that it helped me in perfecting article writing. Also to my family, relatives and friends who always provide prayers so that I am excited in writing this article.

\section{References}

1. Adriani M. dan Bambang Wirjatmadi, Peranan Gizi Dalam Siklus Kehidupan. Jakarta: Kencana Prenada Media Group; 2015.

2. Ali A. Menguak Teori Hukum (Legal Theory) Dan Teori Peradilan (Judicial Prudence), Ke 5. Jakarta: Kharisma Putra Utama; 2013.

3. Anugraheni HS, Kartasurya MI. Faktor Risiko Kejadian Stunting Pada Anak Usia 12-36 Bulan di Kecamatan Pati, Kabupaten Pati. Semarang: Eprints Undip; 2012. 
4. Awaludin H, Politik HA. Hukum dan Kemunafikan Internasional, PT. Jakarta: Kompas Media Nusantara; 2011.

5. Bloem MW, Brinkman HJ, de Pee S, Sanogo I, dan Subran L. High food prices and the global financial crisis have reduced access to nutritious food and worsened nutritional status and health. J Nutr. 2010;140(1):153S-61.

6. Kementerian Kesehatan RI. Pusdatin: Situasi Balita Pendek (Stunting) di Indonesia. Jakarta: Kementerian Kesehatan RI; 2018.

7. Kurnia TS. Hak Atas Derajat Kesehatan Optimal Sebagai HAM di Indonesia PT. Bandung: Alumni; 2007.

8. El Majda M. Dimensi Dimensi HAM (Mengurai Hak EKonomi, Sosial Dan Budaya). Jakarta: PT. Rajawali Pers; 2008.

9. Neta Y. Partisipasi Masyarakat Penegakan Hak Asasi Manusia di Negara Demokrasi. Jakarta: Monograf; 2013.

10. Rahardjo S. Negara Hukum Yang Membahagiakan Rakyatnya. Yogyakarta: Genta Press; 2008.

11. Satriawan E. Strategi Nasional Percepatan Pencegahan Stunting 2018-2024. Jakarta: Tim Nasional Percepatan Penanggulangan Kemiskinan (TNP2K); 2018.

12. Soekanto S. Pengantar Penelitian Hukum. Jakarta: Universitas Indonesia Press; 2012.

13. Waluyo B. Penelitian Hukum Dalam Praktik. Jakarta: Penerbit Sinar Grafika; 2011.

14. Astari LD, dan Nasoetion A, Dwiriani CM. Hubungan karakteristik keluarga, pola pengasuhan dan kejadian stunting anak usia 6-12 Bulan. Int J Med. 2005;29(2):40-6.

15. Black RE, Allen LH, Bhutta ZA, Caulfield LE, Onis MD, Ezzati $\mathrm{M}$, et al. Maternal and child undernutrition: Global and regional exposures and health consequences. Lancet. 2008;371(9608):243-60. https://doi.org/10.1016/ S0140-6736(07)61690-0 PMid:18207566

16. Husaini M. Studi faktor sosio-budaya yang mempengaruhi giz dan kebiasaan hidup sehat di martapura-kalimantan Selatan. Bull Health Res. 2012;26(2):1-11.

17. Izwardi D. Kebijakan dan Strategi Penanggulangan Kemiskinan di Indonesia. Dinamika Pedesaaan dan Kawasan. 2019;2(2):31.

18. Diana M. Stunting, faktor resiko dan pencegahannya stunting, risk factors and prevention. J Kedokteran. 2018;5(1):1-6.

19. Mugianti SZ, Mulyadi A, dan Lukluin AK. Faktor penyebab anak stunting usia 25-60 bulan di kecamatan sukorejo kota blitar 1. J Kebidanan. 2018;5(2):23362.

20. Mugianti S, Mulyadi A, dan Lukluin AK. Faktor penyebab anak stunting usia 25-60 bulan di kecamatan sukorejo kota Blitar 1. J Kebidanan. 2018;5:1-11.

21. Mustafa S. Permasalahan anak pendek (stunting) dan intervensi untuk mencegah terjadinya stunting (suatu kajian kepustakaan) stunting problems and interventions to prevent stunting (a literature review). J Kesehatan Komunitas. 2015;2(5):254-61. 